Wiesława Jednaka

ORCID: 0000-0001-9838-2788

Uniwersytet Wrocławski

\title{
Nowo powstałe partie małe w Polsce a wybory 2010-2011. Progi rozwoju partii*
}

\author{
DOI: $10.19195 / 1643-0328.25 .6$
}

Słowa kluczowe: partia mała, wybory, program partii, progi rozwoju partii

\section{Wprowadzenie}

Kampania wyborcza to istotne wydarzenie, które pozwala wyborcy poddać gruntownej analizie uczestników rywalizacji wyborczej na podstawie ich dotychczasowej działalności, realizacji programu lub stopnia spełnienia obietnic wyborczych. $Z$ reguły elektorat popiera to ugrupowanie, z którym się identyfikuje, poprzez akceptację jego oferty wyborczej (merytoryczna ocena programu $)^{1}$. I. Budge i D. Farlie nazywają to zjawisko racjonalnym wyborem $^{2}$. Z tego punktu widzenia ważkim wydarzeniem kampanii wyborczej jest przystąpienie do niej nowych formacji, które nie są znane wyborcom, lub takich, które zostały utworzone przez polityków dotychczas funkcjonujących w innych partiach politycznych lub które powstały w efekcie rozłamu bądź rozpadu jakiegoś ugrupowania ${ }^{3}$ czy też fuzji

* Artykuł powstał w ramach realizacji projektu badawczego własnego o numerze N N116300238, sfinansowanego przez MNiSW.

1 Tego typu głos to głos opinii. Wyróżniamy jeszcze głos wymiany i głos przynależności. Zob. A. Parisi, G. Pasquino, Changes in Italian Electoral Behaviour: The Relationships between Parties and Voters, [w:] Italy in Transition, red. P. Lange, S. Tarrow, London 1980, s. 14, 15; W. Jednaka, Proces kształtowania sie systemu partyjnego w Polsce po 1989 r., Wrocław 1995, s. 53; eadem, Zachowania wyborcze, [w:] Demokracje zachodnioeuropejskie. Analiza porównawcza, red. A. Antoszewski, R. Herbut, Wrocław 2008, s. 309, 310.

2 I. Budge, D. Farlie, Explaining and Predicting Elections. Issue Effects and Party Strategies in 23 Democracies, London 1983, s. 7; W. Jednaka, Zachowania wyborcze..., s. 311, 312.

3 P. Mair, New Political Parties in Established Party System: How Successful Are They?, [w:] Elities, Parties and Democracy: Festschrift for Professor Mogens N. Pedersen, red. E. Beukel, K.K. Klausen, P.E. Mouritzen, Odense 1999, s. 207-224; A. Krouwel, P. Lucardie, Waiting in the wings: New parties in the Netherlands, „Acta Politica" 43, 2008, s. 278-307. Na temat partii nowych w polskim piśmiennictwie zob.: M. Marmola, Nowe partie polityczne w Polsce, Czechach i na Słowacji z perspektywy geografii wyborczej, „Political Preference” 
kilku ugrupowań $\mathrm{w}$ jedno $-\mathrm{z}$ reguły większe $-\mathrm{z}$ nową ofertą programową, likwidując poprzednie partyjne struktury organizacyjne ${ }^{4}$. Powstaje zatem pytanie o programy tych formacji, poziom realności ich realizacji oraz przedmiot i zakres proponowanych kwestii społecznych, ekonomicznych i politycznych, które zostały zawarte w ich programach.

Celem niniejszego artykułu będzie analiza trzech elekcji: w 2010 r. samorządowej i prezydenckiej, a w $2011 \mathrm{r}$. parlamentarnej z perspektywy uczestniczenia w nich nowo powstałych ${ }^{5}$ partii małych, a zatem ich aktywności wyborczej (uczestnictwo w elekcjach), propozycji programowych, zdobyczy wyborczych oraz konkluzji dotyczących ich progów rozwoju według koncepcji M. Pedersena. W artykule będę analizowała tylko te partie, które powstały po wyborach parlamentarnych $2007 \mathrm{r}$. Pominięte zostaną formacje obecne na scenie politycznej (partie mainstreamowe) ${ }^{6}$ w latach 2010-2011. Stosując pojęcie „partie małe”, odnoszę je do koncepcji P. Maira, który zaproponował podejście numeryczne, czyli oceniał „małość" partii przez zastosowanie kryterium rozmiaru? ${ }^{7}$. W przypadku polskich ugrupowań politycznych minimalny poziom poparcia wyborczego w ujęciu P. Maira, pozwalający zaliczyć je do kategorii partii małych (1\%), jest dosyć wysoki. Przyjęłam, że za partię małą uważać będę tę partię, która zdobyła co najmniej 1 głos, nie więcej jednak niż $15 \%$.

\section{Partie małe w elekcjach 2010-2011}

W Polsce obowiązuje system rejestracji ${ }^{8}$ partii, w efekcie którego ugrupowanie polityczne, chcące wziąć udział w wyborach, musi złożyć dokumenty w Sądzie Okręgowym w Warszawie, w celu wpisania go do ewidencji partii politycznych (szerzej: w dalszej części artykułu). Cykl wyborczy w Polsce, w omawianym okresie, otwierały wybory prezydenckie 20 czerwca 2010 r., następnie 21 listopada 2010 r. wybory samorządowe, a niespełna rok później, 9 października 2011, odbyła się elekcja do parlamentu. W ewidencji partii w latach 2010-2011 przybyło dziesięć nowych ugrupowań politycznych: Chrześcijańska Inicjatywa Społeczna (2007), Samoobrona Patriotyczna (2007), Prawica Rzeczypospolitej

17, 2017, s. 57-72; W. Wojtasik, Nowa partia w systemie partyjnym, [w:] J. Juchnowski, R. Wiszniowski, Studia nad wspótczesnymi studiami politycznymi, t. 1. Podmioty i procesy demokratyczne. Księga dedykowana profesorowi Andrzejowi Antoszewskiemu, Toruń 2014.

4 T.R. Rochon, Mobilizer and challenges: Towards a theory of new party success, „International Political Science Review" 6, 1985, nr 4.

${ }^{5}$ Za cezurę przyjęto okres po elekcji parlamentarnej w 2007 r., ponieważ kolejne wybory miały odbyć się dopiero za trzy lata (w 2010 r.). Jeśli zatem w tym czasie powstawały nowe ugrupowania polityczne, to można przyjąć, iż po to, aby uczestniczyć w rywalizacji wyborczej, której celem jest zdobycie władzy. Zob. R. Herbut, Instytucjonalizacja partii, [w:] Demokracje zachodnioeuropejskie..., s. 78, 79.

${ }^{6}$ B. Meguid, Party competition between unequals. Strategies and electoral fortunes in Western Europe, http://dx.doi.org/10.1017/CBO9780511510298, s. 2 (dostęp: 15.04.2010); P. Sula, Partie małe w wybranych państwach Europy Środkowo-Wschodniej w latach 1989-2016, Kraków 2018, s. 37.

7 P. Mair, The Electoral Universe of Small Parties in Postwar Western Europe, [w:] Small Parties in Western Europe. Comparative and National Perspectives, red. F. Muller-Rommel, G. Pridham, London 1991, s. 47.

8 Art. 11 ustawy z dnia 27 czerwca 1997 r. o partiach politycznych, t.j. Dz.U. z 2018, poz. 580. 
(2007), Polska Patriotyczna (2008), Przymierze Narodu Polskiego (2009), Lepsza Polska (2010), Ruch Palikota (2011), Partia Rozwoju (2011), Partia Kierowców - Bezprawiu Stop (2011) oraz Kongres Nowej Prawicy (2011). Spośród tych dziesięciu formacji cztery były nowymi organizmami politycznymi z liderami niefunkcjonującymi dotychczas w przestrzeni politycznej, pozostałe sześć to zaś partie, które powstały w wyniku secesji $\mathrm{z}$ innej formacji politycznej.

Chrześcijańska Inicjatywa Społeczna ${ }^{9}$ została zarejestrowana w roku 2007 przez działaczy z Dolnego i Górnego Śląska z siedzibą we Wrocławiu. Wykazywała aktywność w dwóch ośrodkach miejskich: we Wrocławiu i Gliwicach. W stolicy Dolnego Śląska wystawiła kandydatkę na urząd prezydenta miasta, która zajęła ósme, przedostatnie miejsce, zdobywając 699 głosów ${ }^{10}$. Po elekcji parlamentarnej 2011 ChIS nie uczestniczyła w innych kampaniach wyborczych. W 2014 została wykreślona z ewidencji partii politycznych ${ }^{11}$.

Samoobrona Patriotyczna ${ }^{12}$ powstała w roku 2007 z inicjatywy części byłych działaczy Samoobrony Rzeczypospolitej ${ }^{13}$. Działała w zasadzie tyko na terenie województwa lubelskiego. O ile w elekcji 2007 wystartowała w wyborach parlamentarnych, wystawiając kandydatów w wyborach do Sejmu i Senatu, o tyle w 2010 przystąpiła już tylko do wyborów municypalnych i tylko do rad powiatu i sejmiku województwa, również w okręgu lubelskim. Po porażkach wyborczych w 2007 i 2011 zaprzestała swojej działalności politycznej, a duża część jej działaczy przeszła do partii politycznej o nazwie Polska Patriotyczna, która została utworzona przez działaczy Samoobrony Patriotycznej w 2008 r., działającej równolegle do czasu wykreślenia Samoobrony Patriotycznej z wykazu partii. Polska Patriotyczna nadal znajduje się w ewidencji partii politycznych.

Prawica Rzeczypospolitej ${ }^{14}$ zarejestrowana została w 2007 r. w wyniku opuszczenia Prawa i Sprawiedliwości przez Marka Jurka, ówczesnego wiceprezesa partii, po braku wsparcia przez PiS projektu ustawy o ochronie życia od momentu poczęcia do naturalnej śmierci. Partia regularnie uczestniczy we wszystkich kampaniach wyborczych. W 2010 r. w elekcji municypalnej nie obsadziła żadnego mandatu. W wyborach prezydenckich kandydował jej lider Marek Jurek, zajmując ósme miejsce. Również w wyborach parlamentarnych Prawica Rzeczypospolitej nie odniosła sukcesu. Nadal jest obecna w rejestrze partii politycznych.

Przymierze Narodu Polskiego ${ }^{15}$ powstało w 2009 r. Wzięło udział w wyborach samorządowych, ale bez powodzenia. W elekcji prezydenckiej nie uczestniczyło. Przed

9 http://www.chis.com.pl (dostęp: 7.12.2010).

10 http://wybory2010.pkw.gov.pl/geo/pl/020000/026401.html\#tabs-6 (dostęp: 15.04.2011).

11 https://www.imsig.pl/pozycja/2014/171/12046,CHRZE\%C5\%9ACIJA\%C5\%83SKA_INICJATYWA_SPO\%C5\%81ECZNA (dostęp: 9.02.2008).

$\overline{12}$ http://www.spatriotyczna.za.pl (dostęp: 21.11.2010).

13 Samoobrona RP powstała na bazie Związku Zawodowego Rolnictwa „Samoobrona”, której liderem (podobnie jak ZZR „S”) był A. Lepper. Początkowo (1992) przyjęła nazwę „Przymierze Samoobrona”, po czym w roku 2000 przemianowała się na Samoobronę Rzeczypospolitej. Po porażce w wyborach parlamentarnych w 2007 oraz tzw. aferze gruntowej część jej działaczy (wraz z A. Lepperem) założyła w 2010 nową partię polityczną o nazwie „Nasz Dom Polska - Samoobrona Andrzeja Leppera”, po czym w 2011 r. dokonała zmiany nazwy ugrupowania na Samoobronę.

$14 \mathrm{http}: / /$ prawicarzeczypospolitej.org (dostęp: 21.11.2010).

15 http://przymierzenarodupolskiego.org (dostęp: 20.07.2010). 
wyborami parlamentarnymi 2011 wraz z innymi ugrupowaniami prawicowymi partia usiłowała utworzyć koalicję wyborczą z Przymierzem Ludowo-Narodowym, Stronnictwem Ludowym „Ojcowizna”, Ligą Polskich Rodzin i Stronnictwem Narodowym im. Dmowskiego Romana, lecz rozmowy zakończyły się fiaskiem. W roku 2013 wykreślona została $\mathrm{z}$ rejestru partii.

Lepsza Polska ${ }^{16}$ to formacja powstała w 2010 r. z siedzibą w Warszawie. Startowała tylko raz, w wyborach samorządowych w Warszawie. Jej lider ubiegał się o mandat prezydenta Warszawy. Formacja nadal figuruje w wykazie partii politycznych.

Partia Rozwoju ${ }^{17}$ została zarejestrowana w roku 2011 już po raz trzeci. Po raz pierwszy wpisano ją do ewidencji partii w roku 2001, po raz drugi w 2004. Siedziba partii mieści się we Wrocławiu. Partia nie uczestniczy w elekcjach. Ani razu nie wystawiła kandydatów w wyborach prezydenckich, parlamentarnych, samorządowych czy do Parlamentu Europejskiego.

Inicjatywa powołania ugrupowania reprezentującego interesy kierowców pojawiła się po raz pierwszy w sierpniu 2006 r. Przyjęła nazwę „Partia Kierowców”18. Była to partia zaliczana do "the single-issue parties"19. Liderzy opracowali 21 postulatów dotyczących wyłącznie problemów, z którymi borykają się kierowcy. Do innych kwestii partia się nie odnosiła. Celem formacji nie był udział w wyborach, lecz nagłośnienie problemów dotyczących posiadaczy aut lub/i osób zatrudnionych w transporcie i włączenie tych kwestii do programu przez partie mainstreamowe. $\mathrm{Z}$ ich apelu wyborczego skorzystał dwukrotnie Janusz Korwin-Mikke: po raz pierwszy w wyborach prezydenckich w 2010, a po raz drugi w wyborach parlamentarnych $2015^{20}$. W roku 2011 zarejestrowana została kolejna formacja koncentrującą się na tych zagadnieniach, czyli Partia Kierowców Bezprawiu Stop, która również nie zamierzała uczestniczyć w wyborach. Nie była ona kontynuatorką podmiotową formacji z 2006 r. Po dwóch latach, w 2013, wykreślona została z ewidencji partii politycznych.

Ruch Palikota ${ }^{21}$ był partią powstałą w połowie $2011 \mathrm{r}$. z inicjatywy byłego posła PO, Janusza Palikota ${ }^{22}$, który wcześniej utworzył Ruch Poparcia, jednak partia nie złożyła do PKW sprawozdania finansowego za 2010 r. W 2013 r. lider partii dokonał zmiany nazwy partii na: Twój Ruch.

16 www.lepszapolska.com (dostęp: 20.07.2010).

17 www.partia-rozwoju.org (dostęp: 11.01.2011).

18 W Polsce w 2011 r. powstała Partia Kierowców - Bezprawiu Stop. Nie była ona jednak kontynuatorką programową, ideologiczną ani personalną Partii Kierowców z 2006 r. (zob. Leksykon polskich partii politycznych, red. R. Glajcar, A. Turska-Kawa, W. Wojtasik, Toruń 2017, s. 234-235).

19 C. Mudde, The single issue party thesis extreme right parties and the immigration issue, „West European Politics" 22, 1999, nr 3, s. 182-197.

${ }^{20} \mathrm{http}$ ://wmeritum.pl/korwin-mikke-w-obronie-kierowcow-traktowani-sa-w-polsce-jak-dojne-krowywideo/122266 (dostęp: 3.12.2015).

$21 \mathrm{http}: / /$ www.ruchpalikota.org.pl (dostęp: 3.10.2011).

22 Poseł PO zrezygnował z przynależności do klubu parlamentarnego i partii ze względu na konflikt, do jakiego doszło w 2010 r. na tle wypowiedzi tego polityka po katastrofie smoleńskiej. J. Palikot nie chcąc dopuścić do usunięcia go z partii, podjął decyzję o opuszczeniu PO i utworzeniu nowej formacji politycznej. 
Kongres Nowej Prawicy ${ }^{23}$ to ugrupowanie, którego lider, Janusz Korwin-Mikke, jest działaczem partyjnym od 1989 r., kiedy to stanął na czele Unii Polityki Realnej. Regularnie brał udział we wszystkich elekcjach prezydenckich od 1990 do 2015. W omawianym w artykule okresie zarejestrował najpierw w marcu 2010 r. UPR - Wolność i Niepodległość, aby dwa miesiące później, w maju 2010, przekształcić ją w KNP. Brał udział w wyborach prezydenckich (2010) i parlamentarnych (2011). Z powodu konfliktu w partii i po usunięciu go ze stanowiska prezesa partii J. Korwin-Mikke utworzył w 2015 r. nową formację polityczną o nazwie Koalicja Odnowy Rzeczypospolitej Wolność i Nadzieja (KORWiN), która następnie została przekształcona w partię Wolność ${ }^{4}$.

\section{Profil programowy i ideologiczny partii małych w elekcjach 2010-2011}

Formacje biorące udział w elekcjach 2010-2011 mieściły się w większości przypadków w grupie partii prawicowych, choć oczywiście były wyjątki, jak Partia Kierowców Bezprawiu Stop, Ruch Palikota czy Partia Rozwoju.

Partia Kierowców utworzona w 2006 r. przygotowała program składający się z 21 postulatów, które w całości dotyczyły kierowców. Do najważniejszych punktów apelu wyborczego zaliczyć można: zezwolenie na sprowadzanie pojazdów silnikowych zza granicy bez ograniczeń, obniżenie akcyzy do minimalnej wysokości określonej przez Komisję Europejską i przeznaczanie jej na infrastrukturę drogową, budowę torów wyścigowych i system doszkalania kierowców, zniesienie obowiązku ubezpieczenia $\mathrm{OC}$ z wyłączeniem przypadków odszkodowania od trwałego kalectwa lub śmierci uczestnika wypadku drogowego, zmianę limitu dopuszczalnego stężenia alkoholu we krwi z obowiązującego na poziomie 0,2 promila alkoholu we krwi do 0,6 promila dla kobiet i 1,0 promila dla mężczyzn ${ }^{25}$. Kontynuatorką nagłaśniania problemów użytkowników pojazdów mechanicznych była Partia Kierowców - Bezprawiu Stop. Lider formacji zwracał uwagę na nadmierne działania interwencyjne i kontrolujące kierowców (mając na myśli służbę celną i innych inspektorów), prowadzące do nadużyć. Zdaniem lidera partii tylko policja drogowa powinna mieć możliwość prowadzenia tego rodzaju działań. Poza tymi dwoma ugrupowaniami, które nie posiadały profilu ideowego, reszta partii małych charakteryzowała się określną ideologią, a ich programy dotyczyły wielu aspektów społeczno-ekonomicznych.

Lepsza Polska ${ }^{26}$ to ugrupowanie obywatelskie o centrolewicowym profilu akcentujące egalitaryzm. Opowiada się za solidarnością społeczną, demokracją pracowniczą w przedsiębiorstwach poprzez obowiązkowe spotkania organizowane przez szefów firm państwowych oraz z udziałem Skarbu Państwa, na które wstęp byłby wolny. Ponadto opowiadała się za trójstopniowym podatkiem progresywnym, energooszczędnym bu-

\footnotetext{
${ }^{23} \mathrm{http} / / /$ prawicarzeczypospolitej.org (dostęp: 21.11.2010).

$24 \mathrm{https} / / /$ wolnosc.pl/z-kazda-chwila-kurczy-sie-twoja-wolnosc/ (dostęp: 18.07.2015).

25 www.partiakierowcow.org.pl/program (dostęp: 11.06.2006).

26 www.lepszapolska.com/program (dostęp: 20.07.2010).
} 
downictwem przy uproszczonej procedurze, zakazem upraw GMO, zagwarantowaniem godnego, zdrowego życia.

Program Samoobrony Patriotycznej ${ }^{27}$ w zasadzie nie różnił się od programu Samoobrony RP. Podobnie prezentował się program Polski Patriotycznej ${ }^{28}$. Obie formacje akcentowały kwestie narodowe i patriotyczne. Promowały wartości chrześcijańskie i etykę w życiu społecznym i politycznym. Przeciwne wyprzedaży majątku publicznego, popierały renacjonalizację kluczowych gałęzi gospodarki i były eurosceptyczne.

Przymierze Narodu Polskiego ${ }^{29} \mathrm{w}$ kwestiach programowych i aksjologicznych bazuje na zasadach społecznej nauki Kościoła, zwłaszcza jeśli chodzi o model rodziny. Zorientowane na wykorzystywanie narodowego zasobu naturalnego i energii odnawialnej, promocji polskich produktów rolnych, ograniczeniu importu artykułów spożywczych do Polski, przeciwne zasadom gospodarki rynkowej opartej na założeniach liberalnych, popierało objęcie opieką medyczną i socjalną osób bezdomnych i najuboższych.

Prawica Rzeczypospolitej ${ }^{30}$ reprezentuje nurt narodowo-konserwatywno-katolicki. $\mathrm{W}$ kwestiach gospodarczych propaguje poglądy ordoliberalne. W kwestiach społecznych program partii jest oparty na zasadach społecznej nauki Kościoła. Propaguje wartości chrześcijańskie i moralne. Optuje za konstytucyjnymi gwarancjami pełnej ochrony życia, czyli od momentu poczęcia do naturalnej śmierci. Neguje możliwość zawierania związków partnerskich, homoseksualnych, eutanazję, opowiada się za zakazem pornografii (produkcji i rozpowszechniania). W kwestiach funkcjonowania rodziny popiera wzrost wysokości zasiłków porodowych, opiekę nad rodziną wielodzietną, wydłużenie urlopów macierzyńskich, zagwarantowanie świadczeń socjalnych rodzicom, którzy rezygnują z pracy na rzecz wychowywania dzieci, oraz reformę emerytur. Jest przeciwna wszelkiej liberalizacji prawa do aborcji. Popiera wprowadzenie systemu wyborczego większościowego oraz JOW-ów. Mimo eurosceptycyzmu popiera współpracę z Unią Europejską, zwłaszcza w zakresie wpływu na rozdział środków unijnych między kraje członkowskie.

Chrześcijańska Inicjatywa Społeczna ${ }^{31}$ odwołuje się do społecznej nauki Kościoła. Postrzegała siebie jako reprezentację polityczną wszystkich polskich chrześcijan. Zwolenniczka Unii Europejskiej, bazowała na chrześcijańskich korzeniach Europy. Optowała za ochroną rodziny i tradycji narodowej.

Partia Rozwoju ${ }^{32}$ to formacja liberalna. Jej uczestnictwo w życiu politycznym sprowadza się do przedstawiania swojego stanowiska $\mathrm{w}$ istotnych $-\mathrm{z}$ jej punktu widzenia - sprawach.

Ruch Palikota ${ }^{33}$ to ugrupowanie socjalliberalne, antyklerykalne i feministyczne. Partia opowiadała się za legalizacją aborcji, rejestracją związków partnerskich, finansowaniem ze środków budżetowych metody zapłodnienia in vitro, wyprowadzeniem nauczania religii

$27 \mathrm{http}: / /$ www.spatriotyczna.za.pl/program (dostęp: 21.11.2010).

$28 \mathrm{http} / / /$ ppatriotyczna.pl/program (dostęp: 23.11.2010).

$29 \mathrm{http} / / /$ przymierzenarodupolskiego.org/program (dostęp: 20.07.2010).

30 http://prawicarzeczypospolitej.org/program (dostęp: 21.11.2010).

31 http://www.chis.com.pl/program (dostęp: 7.12.2010).

32 Leksykon polskich partii politycznych..., s. 271-273.

33 http://www.ruchpalikota.org.pl /program (dostęp: 17.09.2011). 
ze szkól, podniesieniem wieku emerytalnego poprzez wzrost świadczeń emerytalnych za dłuższą pracę, likwidacją powiatów, likwidacją Senatu, obniżeniem składki na armię do $1 \%$ PKB, przekazywaniem 1\% PKB na rozwój kultury, połączeniem składek ZUS i KRUS.

Kongres Nowej Prawicy ${ }^{34}$ reprezentuje nurt konserwatywno-liberalny. Opowiada się za liberalizmem gospodarczym i konserwatyzmem światopoglądowym. Uznaje wolny rynek, praworządność, karę śmierci, system prezydencki, wolność osobistą, słowa i religijną, autonomię Kościoła wobec państwa, jest przeciwny związkom homoseksualnym i partnerskim oraz dyskryminowaniu ateistów.

\section{Udział partii małych w kampaniach wyborczych 2010-2011}

Tylko dwie formacje wystawiły kandydatów na urząd prezydenta RP i w obu przypadkach byli to liderzy partii. Prawica Rzeczypospolitej wystawiła Marka Jurka, a Kongres Nowej Prawicy Janusza Korwin-Mikkego. Bardziej złożone jest uczestnictwo partii małych w wyborach parlamentarnych, ponieważ spośród ugrupowań, które zdecydowały się na udział w rywalizacji, nie wszystkie startowały do obu izb parlamentu i nie wszystkie zarejestrowały wystarczającą liczbę list, aby móc wystawić kandydatów we wszystkich 41 okręgach wyborczych do Sejmu. O mandaty wyłącznie do Sejmu ubiegali się tylko reprezentanci Ruchu Palikota, nie uczestnicząc w rywalizacji wyborczej do Senatu. Do Sejmu i Senatu wystawili kandydatów liderzy Kongresu Nowej Prawicy i Prawicy Rzeczypospolitej ${ }^{35}$. Z kolei wyłącznie do Senatu wystawiła kandydatów Chrześcijańska Inicjatywa Społeczna. Do wyborów samorządowych przystąpiło pięć ugrupowań: Lepsza Polska, Polska Patriotyczna, Prawica Rzeczypospolitej, Samoobrona Patriotyczna oraz Chrześcijańska Inicjatywa Społeczna.

Prawica Rzeczypospolitej utworzyła samodzielny komitet wyborczy do sejmików wojewódzkich, natomiast na szczeblu powiatów i gmin utworzyła komitety wyborcze pod nazwą Wspólnota Samorządowa Prawicy z małymi ugrupowaniami prawicowymi, takimi jak m.in. Unia Polityki Realnej, Porozumienie Polskie, Stronnictwo Pracy czy Polskie Forum Ludowo-Chrześcijańskie „Ojcowizna”. Rok później, w wyborach parlamentarnych 2011, utworzyła Komitet Wyborczy „Prawica”, na którego listach znaleźli się m.in. działacze UPR, Polskie Forum Ludowo-Chrześcijańskie „Ojcowizna”, Polska Patriotyczna, niektórzy członkowie LPR. KW Prawica Rzeczypospolitej zarejestrował listy w 20 na 41 okręgów wyborczych (378 kandydatów do Sejmu i 13 kandydatów do Senatu). Nie udało się jednak obsadzić ani jednego mandatu. Powyższe dane przedstawia tabela 1.

${ }^{34} \mathrm{http} / / / \mathrm{knp}$. org.pl/program (dostęp: 6.06.2011).

35 Kongres Nowej Prawicy zarejestrował listy w 21 okręgach wyborczych do Sejmu, z kolei Prawica Rzeczypospolitej w 20 okręgach wyborczych — zob. http://wybory2011.pkw.gov.pl/wyn/pl/000000.html\#tabs-1 (dostęp: 21.11.2011). 
Tabela 1. Udział zarejestrowanych przed wyborami partii politycznych w elekcjach 2010-2011

\begin{tabular}{l|c|c|c|c}
\hline \multicolumn{1}{c|}{ Nazwa partii } & $\begin{array}{c}\text { Wybory } \\
\text { samorządowe } \\
2010\end{array}$ & $\begin{array}{c}\text { Wybory } \\
\text { prezydenckie } \\
2010\end{array}$ & $\begin{array}{c}\text { Wybory } \\
\text { parlamentarne } \\
2011 \text { (Sejm) }\end{array}$ & $\begin{array}{c}\text { Wybory } \\
\text { parlamentarne } \\
2011 \text { (Senat) }\end{array}$ \\
\hline Chrześcijańska Inicjatywa Społeczna & + & & & + \\
\hline Prawica Rzeczypospolitej & + & + & + & + \\
\hline Samoobrona Patriotyczna & + & & & \\
\hline Przymierze Narodu Polskiego & + & & & + \\
\hline Lepsza Polska & + & & & + \\
\hline Polska Patriotyczna & + & & & + \\
\hline Ruch Palikota & & + & + & + \\
\hline Partia Rozwoju & & + & & + \\
\hline Partia Kierowców & & & & + \\
\hline Kongres Nowej Prawicy & & & & + \\
\hline
\end{tabular}

Źródło: opracowanie własne na podstawie danych Państwowej Komisji Wyborczej, www.pkw.gow.pl.

Udział w wyborach samorządowych nowych partii ilustruje tabela 2. Na pięć formacji uczestniczących w elekcji municypalnej Polska Patriotyczna i Prawica Rzeczypospolitej zarejestrowały najwięcej list i tylko one uczestniczyły w wyborach do sejmików wojewódzkich, choć nie na terenie całego $\mathrm{kraju}^{36}$. Żadne $\mathrm{z}$ analizowanych ugrupowań nie zarejestrowało list do rad dzielnic miasta stołecznego Warszawy, choć o urząd prezydenta stolicy ubiegały się dwa ugrupowania, a mianowicie Lepsza Polska oraz Prawica Rzeczypospolitej (zob. tabela 3), jednak żadne z nich nie otrzymało wystarczającego poparcia elektoratu Warszawy na obsadzenie tego stanowiska. Niemal wszystkie ugrupowania, poza Samoobroną Patriotyczną, zarejestrowały listy do rad miasta na prawach powiatu, choć nie ubiegały się o uzyskanie legitymacji do wszystkich rad, a zaledwie do dwóchtrzech w danym okręgu wyborczym. Tylko trzy formacje: Polska Patriotyczna, Prawica Rzeczypospolitej oraz Samoobrona Patriotyczna zarejestrowały listy do rad powiatu, ale i w tym przypadku ta ostatnia walczyła o mandaty do jednej tylko rady, Prawica Rzeczypospolitej zaś do czterech. Najlepiej wyglądała sytuacja w odniesieniu do rad gmin w przypadku Prawicy Rzeczypospolitej oraz Polski Patriotycznej. Z kolei Lepsza Polska i Samoobrona Patriotyczna w ogóle nie utworzyły list do tego najbardziej podstawowego szczebla reprezentacji lokalnej.

${ }^{36}$ W wyborach do sejmików wojewódzkich Polska Patriotyczna przystąpiła do rywalizacji w dwóch województwach: wielkopolskim (uzyskała 0,24\% głosów) i mazowieckim $(0,24 \%$ ), w skali kraju zdobywając 0,05\% poparcia. Z kolei Prawica Rzeczypospolitej startowała w siedmiu województwach, uzyskując następujący procent poparcia wyborczego: $\mathrm{w}$ małopolskim $-1,63 \%$, w mazowieckim $-1,34 \%$, w pomorskim - 0,32\%, w śląskim - 1,18\%, w świętokrzyskim - 1,11\%, w wielkopolskim - 0,26\%, w zachodniopomorskim - 1,47\%, co w skali kraju dało tej partii 0,62\% głosów - zob. http://wybory2010.pkw.gov.pl/ geo/pl/000000.html (dostęp: 30.11.2010). 
Tabela 2. Liczba zarejestrowanych list w wyborach samorządowych 2010 r. (liczba list/liczba rad)

\begin{tabular}{l|c|c|c|c|c}
\hline $\begin{array}{l}\text { Nazwa ugrupowania/ } \\
\text { Zarejestrowane listy }\end{array}$ & $\begin{array}{c}\text { Sejmiki } \\
\text { wojewódzkie }\end{array}$ & $\begin{array}{c}\text { Rady } \\
\text { powiatu }\end{array}$ & $\begin{array}{c}\text { Rady miast } \\
\text { na prawach } \\
\text { powiatu }\end{array}$ & $\begin{array}{c}\text { Rad dzielnic } \\
\text { m.st. } \\
\text { Warszawy }\end{array}$ & $\begin{array}{c}\text { Rady } \\
\text { gmin }\end{array}$ \\
\hline Chrześcijańska Inicjatywa Społeczna & - & - & $8 / 2$ & - & $3 / 2$ \\
\hline Lepsza Polska & - & - & $5 / 1$ & - & - \\
\hline Polska Patriotyczna & 5 & 5 & 9 & - & 68 \\
\hline Prawica Rzeczypospolitej & $32 / 7$ & $12 / 4$ & $14 / 3$ & - & $71 / 31$ \\
\hline Samoobrona Patriotyczna & - & $1 / 1$ & - & - & - \\
\hline
\end{tabular}

Źródło: opracowanie własne na podstawie: www.pkw.gow.pl.

Istotna wydaje się także liczba zarejestrowanych kandydatów w wyborach samorządowych. Ilustruje ona problemy partii małych z zapleczem wyborczym, a zwłaszcza z wystarczającą liczbą kandydatów. Najwięcej wystawiła ich Prawica Rzeczypospolitej

Tabela 3. Liczba zarejestrowanych kandydatów w wyborach samorządowych $2010 \mathrm{r}$.

\begin{tabular}{|c|c|c|c|c|c|c|c|}
\hline Nazwa ugrupowania ${ }^{37}$ & $\begin{array}{c}\text { Sejmiki } \\
\text { woje- } \\
\text { wódzkie }\end{array}$ & $\begin{array}{c}\text { Rady } \\
\text { po- } \\
\text { wiatu }\end{array}$ & $\begin{array}{c}\text { Rady miast } \\
\text { na prawach } \\
\text { powiatu }\end{array}$ & $\begin{array}{l}\text { Rady dziel- } \\
\text { nic m.st. } \\
\text { Warszawy }\end{array}$ & $\begin{array}{l}\text { Rady } \\
\text { gmin }\end{array}$ & $\begin{array}{c}\text { Wójt/ } \\
\text { burmistrz/ } \\
\text { prezydent }\end{array}$ & $\begin{array}{l}\text { Ogó- } \\
\text { łem }\end{array}$ \\
\hline ChIS $^{38}$ & - & - & 46 & - & 5 & 1 & 52 \\
\hline Lepsza Polska ${ }^{39}$ & - & - & 30 & - & - & 1 & 31 \\
\hline Polska Patriotyczna ${ }^{40}$ & 35 & 42 & 98 & - & 87 & 7 & 269 \\
\hline Prawica Rzeczypospolitej ${ }^{41}$ & 284 & 63 & 97 & - & 114 & 4 & 562 \\
\hline Samoobrona Patriotyczna ${ }^{42}$ & - & 3 & - & - & - & - & 3 \\
\hline
\end{tabular}

Źródło: opracowanie własne na podstawie: http://wybory2010.pkw.gov.pl/kom/pl/pkw.html (dostęp: 30.11.2010).

37 Chrześcijańska Inicjatywa Społeczna wystawiła kandydatów tylko w dwóch województwach: dolnośląskim i śląskim. Lepsza Polska zarejestrowała listy tylko w województwie mazowieckim. Polska Patriotyczna zarejestrowała kandydatów w pięciu województwach: lubelskim, lubuskim, łódzkim, mazowieckim wielkopolskim. Prawica Rzeczypospolitej wystawiła kandydatów w dwunastu województwach: kujawsko-pomorskim, lubelskim, lubuskim, małopolskim, mazowieckim, opolskim, podkarpackim, pomorskim, śląskim, świętokrzyskim, wielkopolskim, zachodniopomorskim. Samoobrona Patriotyczna wystawiła kandydatów tylko w województwie mazowieckim - http://wybory2010.pkw.gov.pl (dostęp: 30.11.2010).

$38 \mathrm{http} / / /$ wybory2010.pkw.gov.pl/kom/pl/pkw/2c9682212b5dd358012b66f3c84d2a82.html (dostęp: 30.11.2010).

39 http://wybory2010.pkw.gov.pl/kom/pl/pkw/2c9682212b33d0af012b3498813d0227.html (dostęp: 30.11.2010).

40 http://wybory2010.pkw.gov.pl/kom/pl/pkw/2c9682212b33d0af012b3833f5d50255.html (dostęp: 30.10.2010).

41 http://wybory2010.pkw.gov.pl/kom/pl/pkw/2c9682222b43ab9f012b5348e8670bc8.html (dostęp: 30.10.2010).

42 http://wybory2010.pkw.gov.pl/kom/pl/pkw/2c9682212b58b338012b5d430d45101c.html (dostęp: 30.11.2010). 
(562), najmniej Samoobrona Patriotyczna (3). Dla porównania - ugrupowania obecne na scenie parlamentarnej w 2010 r. wystawiły znacznie więcej kandydatów, np. PiS zgłosił ich 31 819, PO - 28 628, PSL - 25 491, a SLD - 19 834. Wymienione partie funkcjonują na scenie politycznej od co najmniej początku XXI w. (PiS i PO) lub - jak PSL i SLD — znacznie dłużej ${ }^{43}$, a to oznacza osiągnięcie przez nie takiego poziomu instytucjonalizacji, który gwarantuje na tyle duże zaplecze wyborcze, aby móc rywalizować na wszystkich szczeblach struktury samorządowej i móc uzyskiwać poparcie pozwalające na sukces wyborczy. Szczegółowe dane zawarto w tabeli 3.

Spośród dziesięciu zarejestrowanych przed wyborami 2010 i 2011 partii w żadnej z elekcji nie uczestniczyły dwie formacje: Partia Rozwoju oraz Partia Kierowców- Bezprawiu Stop.

\section{Progi rozwoju partii w ujęciu M. Pedersena}

M. Pedersen jest autorem koncepcji, według której partie przechodzą w swoim życiu politycznym pewne fazy rozwojowe (progi, bariery). Porównuje on je do cyklów biologicznych, dzięki którym rodzą się one, osiągają dojrzałość lub - jeśli to się nie uda znikają $\mathrm{z}$ areny politycznej, co oznacza ich śmierć polityczną ${ }^{44}$.

Próg deklaracji to pierwszy etap, w myśl którego ugrupowanie deklaruje chęć udziału w wyborach. Może to zrobić np. poprzez zamieszczenie informacji w mediach (dzisiaj również społecznościowych). Przekroczenie tego progu czyni ugrupowanie partią polityczną. W przypadku dziesięciu omawianych partii tylko Partia Kierowców - Bezprawiu Stop i Partia Rozwoju zadeklarowały, że nie będą partycypować w rywalizacji wyborczej. Obie powstały w celu nagłaśniania konkretnego problemu, niereprezentowanego w strategii programowej przez partie mainstreamowe (np. Partia Kierowców - Bezprawiu Stop skoncentrowana na zagadnieniach dotyczących kierowców), lub też w celu odnoszenia się do kwestii, które liderzy partii uważali za istotne i na które chcieli zwracać uwagę w debacie publicznej, aby tym samym nakłonić partie obecne na scenie politycznej do określenia swojego stanowiska w tych sprawach (Partia Rozwoju). Pozostałe formacje deklarowały partycypację w elekcjach 2010-2011. Do rywalizacji wyborczej przystąpiły one, jednak nie do wszystkich trzech i w dość ograniczonym zakresie (nie we wszystkich okręgach wyborczych, zob. tabela 2).

43 SLD i PSL stanowiły kontynuację (w sensie organizacyjnym) formacji z czasów Polskiej Rzeczypospolitej Ludowej (PZPR oraz ZSL). Należy jednak zaznaczyć, że SLD był od 1991 do 1999 r. koalicją wyborczą, na czele której stała partia polityczna będąca kontynuatorką PZPR, czyli Socjaldemokracja Rzeczypospolitej Polskiej (SdRP), która po podjęciu w 1999 r. decyzji o przekształceniu SLD z koalicji wyborczej w partię polityczną przejęła nazwę SLD.

${ }^{44}$ M.N. Pedersen, The dynamics of European party systems: Changing patterns of electoral volatility, „European Journal of Political Research” 7, 1979, nr 1; R. Herbut, W. Jednaka, System partyjny, [w:] Systemy polityczne demokracji zachodnioeuropejskich. Wstęp do analizy porównawczej, red. A. Antoszewski, R. Herbut, Wrocław 1993, s. 104, 105. 
Próg autoryzacji to kolejna bariera w rozwoju partii, której przekroczenie czyni z niej partię polityczną w sensie formalnoprawnym. W myśl ustawy o partiach politycznych ${ }^{45}$ partia musi zostać wpisana do ewidencji partii politycznych, aby mogła uzyskać osobowość prawną. W tym celu niezbędne jest zgłoszenie nazwy partii i jej skrótu, wskazanie adresu siedziby partii, przedstawienie statutu, a także imienia i nazwiska wraz z adresami osób wchodzących w skład organów do reprezentowania partii w czynnościach zewnętrznych i związanych z zaciąganiem zobowiązań majątkowych. Niezbędne jest także zebranie co najmniej 1000 podpisów obywateli popierających zgłoszenie partii do ewidencji ${ }^{46}$. Ten ostatni wymóg nie jest trudny do osiągnięcia, cykliczna analiza wykazu partii politycznych od $1998 \mathrm{r}^{47}$ pokazuje, że nowe partie rejestrowane są dość często, czyli wymóg zebrania 1000 podpisów nie jest przestrzegany restrykcyjnie. Nie dysponujemy jednak danymi dotyczącymi przypadków niepowodzeń w tym zakresie, trudno zatem wnioskować, że w każdym przypadku zamysł utworzenia partii politycznej, a szczególnie spełnienie wymogu zebrania wymaganej liczby podpisów, kończy się powodzeniem.

Próg reprezentacji to trzecia bariera ${ }^{48}$, której przekroczenie oznacza zdobycie mandatów do ciał przedstawicielskich. Udział formacji w elekcjach 2010-2011 zakończył się sukcesem wyborczym tylko w jednym przypadku, a mianowicie Ruchu Palikota w wyborach do Sejmu, do którego uzyskał 10,02\% poparcia (1 439490 głosów), co pozwoliło formacji na obsadzenie 40 mandatów. Pozostałe dwa ugrupowania uczestniczące w wyborach do Sejmu nie zdołały przekroczyć progu 5\% poparcia, który dopuszcza do uczestnictwa w podziale mandatów do izby niższej parlamentu. Kongres Nowej Prawicy w 21 okręgach wyborczych uzyskał łącznie 151837 głosów (1,06\%), Prawicę Rzeczypospolitej poparło zaś 35169 wyborców, czyli 0,24\% ${ }^{49}$. Do Senatu Polska Patriotyczna wystawiła dwóch kandydatów, którzy zajęli ostatnie miejsca, uzyskując najmniejsze poparcie elektoratu $\mathrm{w}$ tych okręgach wyborczych ${ }^{50}$. Wybory samorządowe dla wszystkich pięciu partii, które przystąpiły do rywalizacji wyborczej, zakończyły się porażką.

Próg relewancji opiera się na koncepcji G. Sartoriego, czyli określić go można na podstawie potencjału koalicyjnego lub potencjału szantażu politycznego (groźby politycznej) partii, która wprowadziła swoich reprezentantów do ciał przedstawicielskich ${ }^{51}$. W przypadku tej bariery tylko Ruch Palikota po wyborach parlamentarnych do Sejmu w 2011 r. przekroczył ten próg. Formacja J. Palikota kontrolowała 40 mandatów w Sejmie

45 Ustawa z dnia 27 czerwca 1997 r. o partiach politycznych (Dz.U. z 1997, nr 98, poz. 604 z późn. zm.).

46 Poprzednia ustawa z 28 lipca 1990 r. o partiach politycznych (Dz.U. z 1990, nr 54, poz. 312) przewidywała zebranie jedynie 15 podpisów w celu zarejestrowania partii w ewidencji partii politycznych.

471 stycznia 1998 r. weszła w życie ustawa z 27 czerwca 1997 r. o partiach politycznych (Dz.U. z 1997, nr 98, poz. 604 z późn. zm.).

48 M. Pedersen oba pojęcia, czyli: progi i bariery, stosował zamiennie.

49 http://wybory2011.pkw.gov.pl/wyn/pl/000000.html\#tabs-1 (dostęp: 5.09.2011).

50 W okręgu 82 (Kielce) kandydat PR J. Grudniewski uzyskał 3482 głosy (2,47\%), a w okręgu 40 (Warszawa) Z. Witaszek zdobył 6941 głosów (3,24\%) — zob. http://wybory2011.pkw.gov.pl/wyn/260000/ pl/okr-33.html?id=82\&tab=2\#tabs-3 (dostęp: 21.11.2011).

51 G. Sartori, Parties and Party Systems: A Framework for Analysis, t. 1, Cambridge 1976, s. 122, 123; W. Jednaka, Proces kształtowania się systemu partyjnego..., s. 18; R. Herbut, W. Jednaka, System partyjny..., s. $177-180$. 
VII kadencji, jednak nie była zaproszona przez Platformę Obywatelską do przetargów koalicyjnych, tracąc tym samym potencjał koalicyjny. Platforma Obywatelska zdobyła 207 mandatów, a zatem brakowało jej 24 mandatów do dysponowania większością bezwzględną mandatów w Sejmie, w związku z czym postanowiła kontynuować koalicję gabinetową z PSL (28 mandatów) ${ }^{52}$, a Ruch Palikota przeszedł do opozycji, dysponując potencjałem groźby politycznej wobec rządu premiera D. Tuska. Ruch Palikota często jednak głosował tak samo jak PO i PSL, przynajmniej w odniesieniu do kwestii ekonomicznych.

\section{Podsumowanie}

Partie małe w Polsce, utworzone po wyborach 2007 r., a przed elekcjami 2010-2011, w większości przypadków nie przekroczyły wszystkich czterech progów partii, czyli ich cykl rozwojowy nie rozwijał się w kierunku pozycji relewantnego podmiotu politycznego w systemie partyjnym. Poza dwiema formacjami, które nie uczestniczyły w wyborach, a więc Partią Kierowców - Bezprawiu Stop oraz Partią Rozwoju, reszta ugrupowań przystąpiła, w dość okrojonym zakresie, do rywalizacji wyborczej, przekraczając w ten sposób próg deklaracji. Wszystkie partie małe przekroczyły próg autoryzacji, czyli spełniły kryteria formalnoprawne konieczne do wpisania ich do ewidencji partii politycznych. Problem pojawił się w przypadku próby przekroczenia trzeciego progu, czyli uzyskania reprezentacji. Jak się wydaje, wpływ na to mają trzy czynniki: po pierwsze, programy partii, które nie były dla elektoratu na tyle atrakcyjne, aby zechciał on identyfikować się z którymś z nich i zechciał oddać nań głos. Programy partii nie były całościowym zbiorem propozycji rozwiązań różnych kwestii społecznych, ekonomicznych czy ustrojowych. Często w sposób fragmentaryczny odnosiły się do ważnych $-\mathrm{z}$ jej perspektywy - kwestii, niejednokrotnie w postaci nierozwiniętego hasła. Relatywnie często koncentrowały się na wartościach aksjologicznych. Po drugie, analizowane formacje nie posiadały struktur terenowych, a ten element $\mathrm{z}$ kolei koreluje $\mathrm{z}$ brakiem ustrukturyzowanego zaplecza partyjnego. Tylko Ruch Palikota dysponował strukturami lokalnymi i, jak pokazują wyniki wyborów parlamentarnych w 2011 r., miały one realny wpływ na rezultat wyborczy tej partii. Po trzecie, bariera finansowa (brak możliwości zaciągnięcia zobowiązania majątkowego) uniemożliwiała przeprowadzenie kampanii wyborczej i sprawne funkcjonowanie ugrupowania (np. działania marketingowe rozpowszechniające informacje o partii w mediach, w tym mediach społecznościowych). Tylko jedna formacja, a mianowicie Ruch Palikota, dysponowała środkami finansowymi zebranymi na fundusz wyborczy, co pozwoliło partii poprowadzić kampanię bez zaciągania kredytu ${ }^{53}$ i doprowadziło do obsadzenia 40 mandatów. Ona także, jako jedyna, przekroczyła próg relewancji. Nie dysponowała zdolnością koalicyjną (potencjał koalicyjny), co oznacza, że nie została

\footnotetext{
$52 \mathrm{http://wybory2011.pkw.gov.pl/wsw/pl/000000.html} \mathrm{(dostęp:} \mathrm{5.09.2012).}$

53 http://pkw.gov.pl/pliki/1456228371_bfc762ea0a47d9feaa59bb8177d5c360.pdf (dostęp: 5.09.2012).
} 
zaproszona do przetargów koalicyjnych, formalnie znalazła się zatem w gronie ugrupowań opozycyjnych Sejmu VII kadencji, faktycznie jednak często głosowała podobnie jak koalicja gabinetowa utworzona przez Platformę Obywatelską i Polskie Stronnictwo Ludowe. Poza Ruchem Palikota pozostałych siedem ugrupowań nie odniosło zwycięstwa w żadnej z elekcji, w której uczestniczyły.

\section{Bibliografia}

Budge I., Farlie D., Explaining and Predicting Elections. Issue Effects and Party Strategies in 23 Democracies, London 1983.

Herbut R., Instytucjonalizacja partii, [w:] Demokracje zachodnioeuropejskie. Analiza porównawcza, red. A. Antoszewski, R. Herbut, Wrocław 2008.

Herbut R., System partyjny, [w:] Demokracje zachodnioeuropejskie. Analiza porównawcza, red. A. Antoszewski, R. Herbut, Wrocław 2008.

Herbut R., Jednaka W., System partyjny, [w:] Systemy polityczne demokracji zachodnioeuropejskich. Wstęp do analizy porównawczej, red. A. Antoszewski, R. Herbut, Wrocław 1993.

Jednaka W., Proces kształtowania się systemu partyjnego w Polsce po 1989 r., Wrocław 1995.

Jednaka W., Zachowania wyborcze, [w:] Demokracje zachodnioeuropejskie. Analiza porównawcza, red. A. Antoszewski, R. Herbut, Wrocław 2008.

Krouwel A., Lucardie P., Waiting in the wings: New parties in the Netherlands, „Acta Politica” 43, 2008.

Leksykon polskich partii politycznych, red. R. Glajcar, A. Turska-Kawa, W. Wojtasik, Toruń 2017.

Mair P., The Electoral Universe of Small Parties in Postwar Western Europe, [w:] Small Parties in Western Europe. Comparative and National Perspectives, red. F. Muller-Rommel, G. Pridham, London 1991.

Mair P., New Political Parties in Established Party System: How Successful Are They?, [w:] Elities, Parties and Democracy: Festschrift for Professor Mogens N. Pedersen, red. E. Beukel, K.K. Klausen, P.E. Mouritzen, Odense 1999.

Marmola M., Nowe partie polityczne w Polsce, Czechach i na Słowacji z perspektywy geografii wyborczej, „Political Preference” 17, 2017, s. 57-72.

Meguid B., Party competition between unequals. Strategies and electoral fortunes in Western Europe, http:// dx.doi.org/10.1017/CBO9780511510298.

Mudde C., The single issue party thesis extreme right parties and the immigration issue, „West European Politics" 22, 1999, nr 3.

Parisi A., Pasquino G., Changes in Italian Electoral Behaviour: The Relationships between Parties and Voters, [w:] Italy in Transition, red. P. Lange, S. Tarrow, London 1980.

Pedersen M.N., The dynamics of European party systems: Changing patterns of electoral volatility, „European Journal of Political Research" 7, 1979, nr 1.

Rochon T.R., Mobilizer and challenges: Towards a theory of new party success, „International Political Science Review" 6, 1985, nr 4.

Sartori G., Parties and Party Systems: A Framework for Analysis, t. 1, Cambridge 1976.

Sikk A., How Unstable? Volatility and genuinely new parties in Eastern Europe, „European Journal of Political Research" 44, 2005, nr 3.

Sula P., Partie małe w wybranych państwach Europy Środkowo-Wschodniej w latach 1989-2016, Kraków 2018.

Ustawa z dnia 28 lipca 1990 r. o partiach politycznych (Dz.U. z 1990, nr 54, poz. 312).

Ustawa z dnia 27 czerwca 1997 r. o partiach politycznych (Dz.U. z 1997, nr 98, poz. 604 z późn. zm.).

Wojtasik W., Nowa partia w systemie partyjnym, [w:] J. Juchnowski, R. Wiszniowski, Studia nad wspótczesnymi studiami politycznymi, t. 1. Podmioty i procesy demokratyczne. Ksiega dedykowana profesorowi Andrzejowi Antoszewskiemu, Toruń 2014. 


\section{Źródła internetowe}

http://pkw.gov.pl/.

http://ppatriotyczna.pl.

http://prawicarzeczypospolitej.org.

http://przymierzenarodupolskiego.org.

http://www.chis.com.pl.

http://www.ruchpalikota.org.pl.

http://www.spatriotyczna.za.pl.

www.lepszapolska.com.

www.partiakierowcow.org.pl.

www.partia-rozwoju.org.

\section{New-created small parties in Poland and participation in the elections 2010-2011. Party thresholds}

Keywords: small party, elections, party program, party thresholds

\section{Summary}

This article analyzes the participation of small parties in the municipal (2010), presidential (2010) and parliamentary (2011) elections. The genesis and programs and ideology of the party have been characterized. The concept of M. Pedersen was used, which describes the party's life cycles. Four party thresholds are included: (1) the declaration threshold - the party declares participation in the elections, (2) the authorization threshold - the party meets the formal and legal requirements contained in the Act on political parties from 1997, (3) the representation threshold - the party wins elections, i.e. receives mandates for representative structures, (4) relevance threshold - G. Sartori's concept is used. On the basis of a comprehensive analysis of party thresholds, small parties have a problem to exceed the threshold of representation. If they do not overcome it, then the fourth threshold, the threshold of relevance, does not apply. Three reasons can be pointed out: the party's program, which is uninteresting to voters, the lack of field structures and the lack of electoral facilities, the lack of financial resources for the election campaign. 